\title{
ANALISIS PENGARUH KREDIT CEPAT AMAN (KCA), KREDIT ANGSURAN SISTEM FIDUSIA (KREASI), KREDIT ANGSURAN SISTEM GADAI (KRASIDA), DAN KREDIT SERBA GUNA (KRESNA) TERHADAP PENDAPATAN SEWA MODAL PADA PT. PEGADAIAN (PERSERO) KANWIL VI MANADO
}

\author{
Oleh : \\ Jane Eiva Siwu \\ Herman Karamoy \\ Sifrid Pangemanan
}

\begin{abstract}
The services product of PT. Pegadaian (Persero), are Credit Fast Secure, Installment Loans Fiduciary System, Installment Loans Pawn System, and Multipurpose Loan. Customer will repay the loan with interest in this case is a capital lease is revenue that received of PT. Pegadaian (Persero) by loans extended. In line with the growth of the existing business can be seen the increase of lease income on lending capital that during 2006 to 2011. This research is analyze the causal's relationship to examine the effect of the fact and phenomena and seek factual information to research that explained on the effect of Credit Fast Secure, Installment Loans Fiduciary System, Installment Loans Pawn System, Multipurpose Loan on Capital Lease Revenue at PT. Pegadaian (Persero) Regional Office VI Manado which is a services products on offer to the public. From these research it can be concluded that Credit Fast Secure, Installment Loans Fiduciary System, Installment Loans Pawn System, Multipurpose Loan, have influence on Capital Lease Revenue at PT. Pegadaian (Persero) Regional Office VI Manado have increase from year to year.
\end{abstract}

Key words : Capital Lease Revenue, Credit 


\section{PENDAHULUAN}

\subsection{Latar Belakang Masalah}

Setiap Perusahaan perlu menyadari bahwa konsumen sebagai pasar sangat menentukan jenis produk dalam setiap kategori, serta memiliki beragam kebutuhan dalam kombinasi serta harga barang dan jasa yang berbeda. Harapan mereka akan mutu dan pelayanan yang tinggi terus meningkat. Di tengah pilihan yang begitu banyak, pelanggan cenderung memilih tawaran yang paling sesuai dengan kebutuhan serta harapan masingmasing mereka dan membeli berdasarkan tata nilai mereka. PT. Pegadaian (Persero) telah menapaki hari-hari panjang sebagai perusahaan yang mengemban amanat Pemerintah membantu meningkatkan kesejahteraan masyarakat dengan menyediakan jasa keuangan yang mudah dan gampang diakses oleh masyarakat menengah ke bawah berdasarkan hukum gadai dan fidusia. Pemanfaatan jasa gadai di Indonesia saat ini telah tersegmentasi berdasarkan geografi dan demografi. PT. Pegadaian (Persero) dalam bisnisnya menyalurkan kredit antara lain Kredit Cepat Aman (KCA),Kredit Angsuran SistemFidusia (KREASI), Kredit Angsuran Sistem Gadai (KRASIDA),dan Kredit Serba Guna (KRESNA). Kredit menurut Malayu S.P. Hasibuan (2009) kredit adalah semua jenis pinjaman yang harus dibayar kembali bersama bunganya oleh peminjam sesuai dengan perjanjian yang telah disepakati. Begitu pula PT. Pegadaian (Persero) atas kredit yang disalurkan maka peminjam mengembalikan pinjaman bersama bunga dalam hal ini sewa modal. Sewa modal adalah merupakan pendapatan yang diterima PT. Pegadaian (Persero) atas kredit yang disalurkan. Dengan adanya perubahan status dari perusahaan umum ke perusahaan perseroan dan akan di keluarkannya Undang-undang monopoli oleh pemerintah maka PT. Pegadaian (Persero) Kanwil VI Manado harus mampu mempertahankan bisnis yang ada dan tetap diminati masyarakat. Karena tidak menutup kemungkinan akan bermunculan lembaga-lembaga gadai lain yang akan menjadi ancaman bagi PT. Pegadaian (Persero) Kanwil VI Manado. Dalam menghadapi persaingan dan mempertahankan bisnis yang ada dimana produk-produk tersebut yang merupakan sumber pendapatan perusahaan maka perusahaan harus memahami faktor-faktor yang mempengaruhi sumber pendapatan perusahaan yang mempengaruhi perusahaan tetap bertahan. Berdasarkan uraian permasalahan di atas dan inkosistensi hasil penelitian sebelumnya, penulis tertarik untuk melakukan penelitian tentang pengaruh Kredit Cepat Aman (KCA), Kredit Angsuran Sistem Fidusia (KREASI), Kredit Angsuran Sistem Gadai (KRASIDA), dan Kredit Serba Guna (KRESNA) terhadap pendapatan sewa modal, dengan pertimbangan teoritis faktor-faktor tersebut berpengaruh terhadap pendapatan sewa modal dalam hal ini pada PT Pegadaian (Persero) Kanwil VI Manado.

\subsection{Rumusan Masalah}

Berdasarkan latar belakang di atas, maka dirumuskanlah beberapa masalah sebagai berikut :

1. Apakah Kredit Cepat Aman (KCA) berpengaruh terhadap Pendapatan Sewa Modal pada PT. Pegadaian (Persero) Kanwil VI Manado ?

2. Apakah Kredit Angsuran Sistem Fidusia (KREASI) berpengaruh terhadap Pendapatan Sewa Modal pada PT. Pegadaian (Persero) Kanwil VI Manado ?

3. Apakah Kredit Angsuran Sistem Gadai (KRASIDA) berpengaruh terhadap Pendapatan Sewa Modal pada PT. Pegadaian (Persero) Kanwil VI Manado ?

4. Apakah Kredit Serba guna (KRESNA) berpengaruh terhadap Pendapatan Sewa Modal pada PT. Pegadaian (Persero) Kanwil VI Manado ?

\subsection{Tujuan Penelitian}

Tujuan dilaksanakannya penelitian ini adalah sebagai berikut :

1. Untuk menganalisa besarnya pengaruh Kredit Cepat Aman (KCA) terhadap Pendapatan Sewa Modal pada PT. Pegadaian (Persero) Kanwil VI Manado.

2. Untuk menganalisa besarnya pengaruh Kredit Angsuran Sistem Fidusia (KREASI) terhadap Pendapatan Sewa Modal pada PT. Pegadaian (Persero) Kanwil VI Manado.

3. Untuk menganalisa besarnya pengaruh Kredit Angsuran Sistem Gadai (KRASIDA) terhadap Pendapatan Sewa Modal pada PT. Pegadaian (Persero) Kanwil VI Manado.

4. Untuk menganalisa besarnya pengaruh Kredit Serba Guna (KRESNA) terhadap Pendapatan Sewa Modal pada PT. Pegadaian (Persero) Kanwil VI Manado.

\subsection{Manfaat Penelitian}

Dengan diketahuinya faktor-faktor yang mempengaruhi pendapatan sewa modal PT.Pegadaian (Persero) Kanwil VI Manado, maka peneliltian ini dapat memberi manfaat kepada: 
1. PT. Pegadaian (Persero) Kanwil VI Manado sebagai bahan kajian dan pertimbangan dalam membuat perencanaan ke depan bagi perusahaan dalam rangka meningkatkan pendapatan sewa modalnya.

2. Para peneliti lain yang akan melakukan penelitian lebih lanjut dapat pula memanfaatkan hasil penelitian ini.

3. Bagi penulis sangat bermanfaat sebagai bahan masukan dan pelengkap dasar-dasar teori sekaligus dalam rangka upaya mencoba menerapkan ilmu pengetahuan teoritis ke dalam praktek nyata dalam menambah wawasan pengetahuan praktis.

\section{TINJAUAN PUSTAKA}

\subsection{Pendapatan}

Ikatan Akuntan Indonesia dalam PSAK No. 23 memberikan pengertian Pendapatan adalah arus masuk bruto dari manfaat ekonomi yang timbul dari aktivitas normal perusahaan selama satu periode bila arus masuk itu mengakibatkan kenaikan ekuitas, yang tidak berasal dari kontribusi penanaman modal.

\subsection{Kredit}

Menurut Undang-Undang Perbankan No.10 Tahun 1998, pengertian kredit adalah penyediaan uang atau tagihan yang dapat dipersamakan dengan itu, berdasarkan persetujuan atau kesepakatan pinjam meminjam antara bank dengan pihak lain yang mewajibkan pihak peminjam untuk melunasi utangnya setelah jangka waktu tertentu dengan pemberian bunga.

\subsection{Pegadaian}

Menurut Kitab Undang-undang hukum Perdata Pasal 1150, gadai adalah hak yang diperoleh seorang yang mempunyai piutang atas suatu barang bergerak. Barang bergerak tersebut diserahkan kepada orang yang berpiutang oleh seseorang yang mempunyai utang atau oleh seorang lain atas nama orang yang mempunyai utang. Seorang yang berutang tersebut memberikan kekuasaan kepada orang berpiutang untuk menggunakan barang bergerak yang telah diserahkan untuk melunasi utang apabila pihak yang berutang tidak dapat memenuhi kewajibannya pada saat jatuh tempo (Sigit dan Totok, 2006).

\subsection{Produk PT. Pegadaian (Persero)}

Berikut ini adalah beberapa produk PT. Pegadaian (Persero) yang menjadi pokok bahasan dalam tulisan ini. Produk-produk ini berpengaruh pada Pendapatan Sewa Modal.

1. Kredit Cepat Aman (KCA)

Kredit Cepat dan Aman (KCA) adalah kredit yang diberikan kepada masyarakat dengan sistem gadai dengan jaminan barang bergerak. Pemberian kredit ini bertujuan untuk membantu pemerintah dalam bidang perekonomian, untuk membantu masyarakat dari gadai gelap, praktek riba dan pinjaman tidak wajar lainnya.

2. Kredit Angsuran Sistem Fidusia (KREASI)

Kredit Kreasi adalah pinjaman (kredit) dalam jangka waktu tertentu dengan menggunakan konstruksi penjaminan kredit secara fidusia, yang diberikan oleh Perum Pegadaian kepada pengusaha kecil yang membutuhkan dana untuk keperluan pengembangan usahanya.

3. Kredit Angsuran Sistem Gadai (Krasida)

Kredit angsuran sistem gadai (Krasida) adalah bentuk layanan pemberian pinjaman kepada masyarakat menengah ke bawah yang mempunyai usaha mikro dan kecil untuk pembiayaan kegiatan usahanya atas dasar hukum gadai yang pelunasannya diangsur setiap bulan sesuai jangka waktu pinjaman. (Pedoman Operasional Kredit KRASIDA 2004).

4. Kredit Serba Guna (Kresna)

Sigit Triandaru dan Totok Budisantoso (2006) dalam buku Bank dan Lembaga Keuangan Lain menyatakan bahwa Kredit serba guna adalah merupakan pemberian pinjaman kepada pegawai/karyawan dalam rangka kegiatan produktif/konsumtif dengan pengembalian secara angsuran.

\subsection{Pendapatan Sewa Modal Pegadaian}

Sewa Modal adalah pendapatan yang di terima PT. Pegadaian (Persero) atas kredit yang disalurkan kepada masyarakat. Menurut Kasmir dalam Sucipto (2006) menyatakan bahwa salah satu tujuan utama dari pemberian kredit yaitu mencari keuntungan atau mendapatkan laba. Mencari keuntungan atau laba maksudnya untuk memperoleh hasil pemberian kredit tersebut. Hasil tersebut terutama dalam bentuk bunga yang diterima oleh perusahaan sebagai balas jasa dan biaya administrasi kredit yang dibebankan kepada nasabah. 


\subsection{Penelitian Terdahulu}

Suci Dwikania S (2011) dalam pelitian "Pengaruh Pemberian Kredit Gadai KCA terhadap Pendapatan Sewa Modal pada Pegadaian Cabang Pungkur Bandun" menyimpulkan bahwa pemberian kredit gadai KCA berpengaruh positif namun tidak signifikan terhadap pendapatan sewa modal, serta memiliki tanda negatif antara pemberian kredit gadai dengan pendapatan sewa modal, dimana semakin besar kredit yang disalurkan, maka pendapatan semakin rendah.

Sucipto (2006) melakukan penelitian dengan judul "Analisis faktor-faktor yang mempengaruhi pendapatan sewa modal pada Cabang Perum Pegadaian Kota Surakarta'. Penelitian ini bertujuan (1) menganalisis besarnya pengaruh kredit gadai konvensional, KREASI dan KRASIDA terhadap pendapatan sewa modal pada Cabang Perum Pegadaian Surakarta (2) mengetahui faktor yang paling dominan berpengaruh terhadap pendapatan sewa modal pada Cabang Perum Pegadaian Surakarta

Pengujian hipotesis ini menggunakan bantuan komputer dengan program SPSS 10, yaitu analisis regresi dengan uji pengaruh (uji t) dan uji kebaikan model (uji $F$ dan R2) juga dengan uji normalitas, uji heteroskedastisitas, uji autokorelasi dan uji multikolinearitas. Hasil penelitian ini dapat disimpulkan bahwa hasil analisis regresi menunjukkan bahwa variabel independen (kredit gadai konvensional dan KREASI) secara individu mempunyai pengaruh positif dan signifikan terhadap pendapatan sewa modal pada Kantor Cabang Perum Pegadaian Surakarta. Sedangkan untuk variabel KRASIDA secara individu mempunyai pengaruh negatif terhadap pendapatan sewa modal pada Kantor Cabang Perum Pegadaian Surakarta. Dari ketiga variabel independen yang ada yang mempunyai pengaruh paling dominan adalah variabel kredit gadai konvensional kemudian KREASI dan yang terendah adalah variabel KRASIDA. Semua variabel independen, yaitu kredit gadai konvensional, KREASI dan KRASIDA pada saat diuji secara bersama-sama mempunyai pengaruh yang signifikan terhadap pendapatan sewa modal. Hal ini dapat dibuktikan dengan uji F. Hasil uji F diketahui bahwa nilai $\mathrm{F}$ hitung sebesar 23,751 > F tabel 3,32. Pemilihan variabel independen untuk mengukur pendapatan sewa modal sudah bagus, hal ini bisa dilihat dari hasil analisis dimana nilai Adjusted $R$ square sebesar 0,922. Artinya $92,2 \%$ variabel pendapatan sewa modal dipengaruhi variabel kredit gadai konvensional, KRASIDA dan KREASI, sedangkan 7,8\% dipengaruhi variabel lain yang tidak diteliti. Berdasarkan hasil uji regresi diketahui bahwa data berdistribusi normal, model tidak terjadi heteroskedastisitas, tidak mengalami autokorelasi dan tidak mengalami multikolinearitas.

\section{KERANGKA KONSEPTUAL}

\subsection{Kerangka Konseptual Penelitian}

Kredit Cepat Aman (KCA) (X1)
Kredit Angsuran Sistem Fidusia (KREASI)
Kredit Angsuran Sistem Gadai (KRASIDA)
Kredit Serba Guna (KRESNA) (X4)

\subsection{Hipotesis}

\section{Gambar 3.1 Kerangka Konseptual Penelitian}

H1 : Kredit Cepat Aman (KCA) berpengaruh terhadap pendapatan sewa modal pada PT Pegadaian (Persero) Kanwil VI Manado

H2 : Kredit Angsuran Sistem Fidusia (KREASI) berpengaruh terhadap pendapatan sewa modal pada PT Pegadaian (Persero) Kanwil VI Manado

H3 : Kredit Angsuran Sistem Gadai (KRASIDA) berpengaruh terhadap pendapatan sewa modal pada PT Pegadaian (Persero) Kanwil VI Manado 
H4 : Kredit Serba Guna (KRESNA) berpengaruh terhadap pendapatan sewa modal pada PT Pegadaian (Persero) Kanwil VI Manado

\section{METODE PENELITIAN}

\subsection{Jenis/Rancangan Penelitian yang Digunakan}

Penelitian ini merupakan penelitian hubungan kausal (causal effect) penelitian ini dirancang untuk menguji pengaruh fakta dan fenomena serta mencari keterangan secara faktual yaitu penelitian yang bersifat menjelaskan mengenai faktor-faktor yang mempengaruhi pendapatan sewa modal pada PT. Pegadaian (Persero) Kanwil VI Manado.

\subsection{Populasi, Sampel, Besar Sampel, dan Teknik Pengambilan Sampel}

Populasi dalam penelitian ini adalah PT. Pegadaian (Persero) yang terdiri dari 12 Kantor wilayah yang tersebar di seluruh Indonesia. Pengambilan sampel dalam penelitian ini dilakukan dengan menggunakan purposive sampling. Dimana sampel yang diambil adalah PT. Pegadaian (Persero) Kanwil VI Manado. Kriteria yang dijadikan sampel dalam penelitian ini adalah :

1. Kemudahan dalam pengambilan data Laporan Keuangan.

2. Keterbatasan waktu, materi dan lokasi.

\subsection{Cara Pengolahan dan Analisis Data}

Cara pengolahan dan analisis data dalam penelitian ini sebagai berikut.

1. Uji Asumsi Klasik

2. Koefisien Korelasi dan Koefisien Determinasi

3. Analisis Regresi Linear Berganda: $Y=a+\beta_{1} X_{1}+\beta_{2} X_{2}+\beta_{3} X_{3}+\beta_{4} X_{4}+\beta_{5} X_{5}+\beta_{6} X_{6}+\beta_{7} X_{7}+e$

4. $\quad$ Uji F dan Uji $t$

\section{ANALISIS DAN PEMBAHASAN HASIL PENELITIAN}

5.1. Uji Asumsi Klasik

1. Uji Normalitas

Tabel 5.1 Uji Normalitas

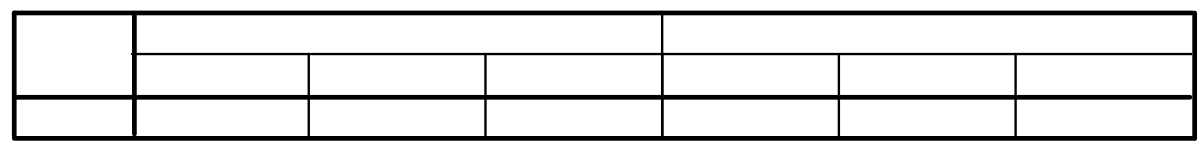

(Sumber : Data Hasil Olahan SPSS)

Berdasarkan uji Kolmogorov Smirnov pada Tabel 5.1 menunjukkan, dimana tingkat signifikansi residual error adalah $0.200>0.05$ sehingga dapat disimpulkan bahwa residual error data terdistribusi dengan normal. Maka model regresi yang digunakan dalam penelitian ini memenuhi asumsi normalitas.

\section{Uji Heteroskedastisitas}

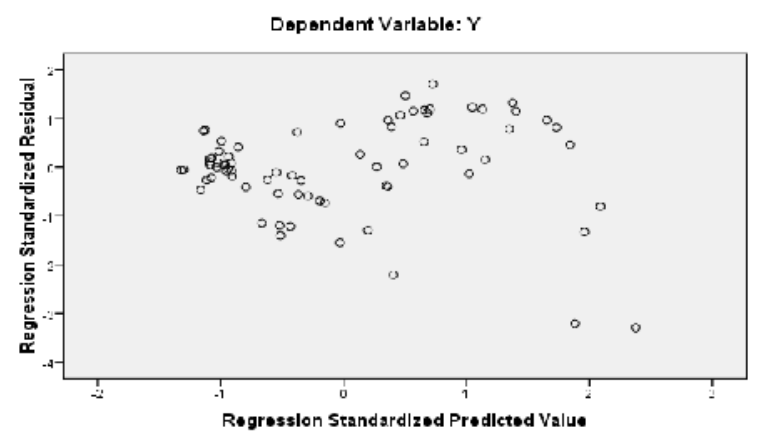

(Sumber : Data Hasil Olahan SPSS)

Gambar 5.1 Uji Heteroskedastisitas 
Pada Gambar 5.1 dapat dilihat bahwa titik-titik tidak membentuk suatu pola yang jelas, serta titik-titik menyebar di atas dan di bawah angka 0 (nol) pada sumbu $\mathrm{Y}$, hal ini membuktikan tidak terjadi heteroskedastisitas.

\section{Uji Multikoleniaritas}

\section{Tabel 5.2 Uji Multikoleniaritas}

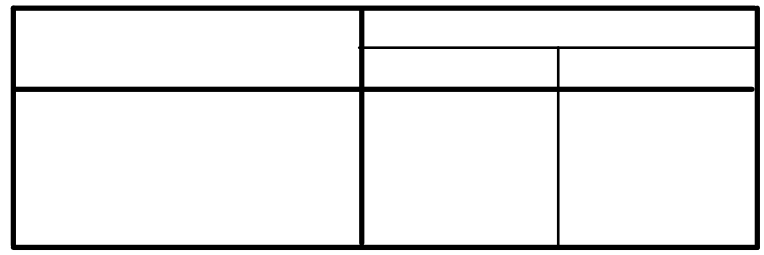

(Sumber : Data Hasil Olahan SPSS)

Berdasarkan hasil coefficients yang terdapat pada tabel 5.2 dapat dilihat pada output coefficients model, dikatakan tidak terjadi gejala multikolinearitas jika $\mathrm{VIF}<5$ dan nilai tolerance $>0,10$.

\section{Uji Autokorelasi}

Berdasarkan tabel 5.3 dengan melihat angka Durbin Watson sebesar 1.496, maka dapat disimpulkan bahwa data penelitian berada di daerah ragu-ragu yang mana tidak ada korelasi.

Tabel 5.3 Uji Autokorelasi

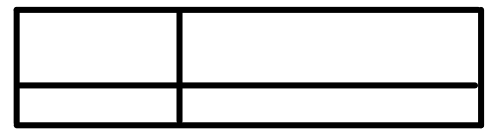

\subsection{Koefisien Korelasi (r) dan Koefisien Determinasi $\left(\mathbf{R}^{2}\right)$}

(Sumber : Data Hasil Olahan SPSS)

Berdasarkan hasil analisis nilai korelasi adalah sebesar 0.979 sehingga dapat disimpulkan bahwa hubungan antara variabel independen dan variabel dependen adalah sangat kuat dari nilai angka koefisien korelasi berkisar 0 sampai dengan \pm 1.00 (artinya paling tinggi \pm 1.00 dan paling rendah 0 ). Hasil analisis korelasi tersebut positif dan arah korelasi satu arah.

\section{Tabel 5.4 Koefisien Determinasi}

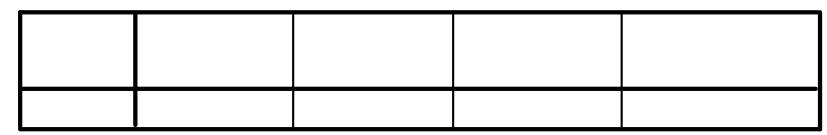

(Sumber : Data Hasil Olahan SPSS)

Dengan melihat tabel 5.4 maka dapat diketahui bahwa besarnya nilai koefisien determinasi $\left(\mathrm{R}^{2}\right)$ adalah sebesar 0.959 yang berarti bahwa kontribusi variabel independen untuk menjelaskan model variabel dependen adalah sebesar $95.7 \%$, sedangkan sisanya dapat dijelaskan oleh faktor-faktor lain yang tidak dimasukkan dalam penelitian ini. 


\subsection{Analisis Regresi Linear Berganda}

$$
\mathrm{Y}=-4.003+2.471 \mathrm{KCA}+0.104 \mathrm{KREASI}+0.022 \mathrm{KRASIDA}+48.336 \mathrm{KRESNA}
$$

Pendapatan Sewa Modal (PSM). Dengan implikasi manajerial sebagai berikut :

1. Nilai PSM adalah sebesar -4.003 yang berarti nilai PSM tidak akan memiliki nilai apabila variabel independen yang lain adalah konstan.

2. Nilai PSM akan mengalami kenaikan Rp. 2.741 apabila terjadi kenaikan Rp. 1 atas KCA sedangkan variabel independen yang lain adalah ceteris paribus.

3. Nilai PSM akan mengalami kenaikan sebesar Rp. 0.104 apabila terjadi kenaikan Rp. 1 atas KREASI sedangkan variabel independen yang lain adalah ceteris paribus.

4. Nilai PSM akan mengalami kenaikan sebesar Rp. 0.022 apabila terjadi kenaikan Rp. 1 atas KRASIDA sedangkan variabel independen yang lain adalah ceteris paribus.

5. Nilai PSM akan mengalami kenaikan sebesar Rp. 48.336 apabila terjadi kenaikan Rp. 1 atas KRESNA sedangkan variabel independen yang lain adalah ceteris paribus.

Hasil regresi ini menunjukkan pengaruh beberapa variabel bebas terhadap variabel tergantung pendapatan sewa modal. Nilai konstan sebesar -4.003 menunjukkan bahwa jika variabel Kredit Cepat Aman (KCA), Kredit Angsuran Sistem fidusia (KREASI), Kredit Angsuran Sistem Gadai (KRASIDA) dan Kredit Serba Guna (KRESNA) dianggap konstan atau sama dengan nol (0) maka pendapatan sewa modal pada PT. Pegadaian (Persero) Kanwil VI Manado adalah sebesar -4.003 satuan rupiah.

Koefisien regresi $\mathrm{X}_{1}$ sebesar 2.741 mengartikan bahwa jika faktor Kredit Cepat Aman (KCA) meningkat sebesar 1 rupiah dari kondisi sebelumnya maka pendapatan sewa modal pada PT. Pegadaian (Persero) Kanwil VI Manado akan meningkat sebesar 2.741 rupiah dari kondisi sebelumnya dengan asumsi variabel lain $\left(\mathrm{X}_{2}, \mathrm{X}_{3}\right.$, dan $\left.\mathrm{X}_{4}\right)$ yang diteliti adalah ceteris paribus.

Koefisien regresi $\mathrm{X}_{2}$ sebesar 0.104 mengartikan bahwa jika faktor Kredit Angsuran Sistem Fidusia (KREASI) meningkat sebesar 1 rupiah dari kondisi sebelumnya maka pendapatan sewa modal pada PT. Pegadaian (Persero) Kanwil VI Manado akan meningkat sebesar 0.104 rupiah dari kondisi sebelumnya dengan asumsi variabel lain $\left(\mathrm{X}_{1}, \mathrm{X}_{3}\right.$, dan $\left.\mathrm{X}_{4}\right)$ yang diteliti adalah ceteris paribus.

Koefisien regresi $\mathrm{X}_{3}$ sebesar 0.022 mengartikan bahwa jika faktor Kredit Angsuran Sistem Gadai (KRASIDA) meningkat sebesar 1 rupiah dari kondisi sebelumnya maka pendapatan sewa modal pada PT. Pegadaian (Persero) Kanwil VI Manado akan meningkat sebesar 0.022 rupiah dari kondisi sebelumnya dengan asumsi variabel lain $\left(\mathrm{X}_{1}, \mathrm{X}_{2}\right.$, dan $\left.\mathrm{X}_{4}\right)$ yang diteliti adalah ceteris paribus.

Koefisien regresi $\mathrm{X}_{4}$ sebesar 48.336 mengartikan bahwa jika faktor Kredit Serba Guna (KRESNA) meningkat sebesar 1 rupiah dari kondisi sebelumnya maka pendapatan sewa modal pada PT. Pegadaian (Persero) Kanwil VI Manado akan meningkat sebesar 48.336 rupiah dari kondisi sebelumnya dengan asumsi variabel lain $\left(\mathrm{X}_{1}, \mathrm{X}_{2}\right.$, dan $\left.\mathrm{X}_{3}\right)$ yang diteliti adalah ceteris paribus.

\section{Tabel 5.5 Uji Regresi Linear Berganda uji Hipotesis}

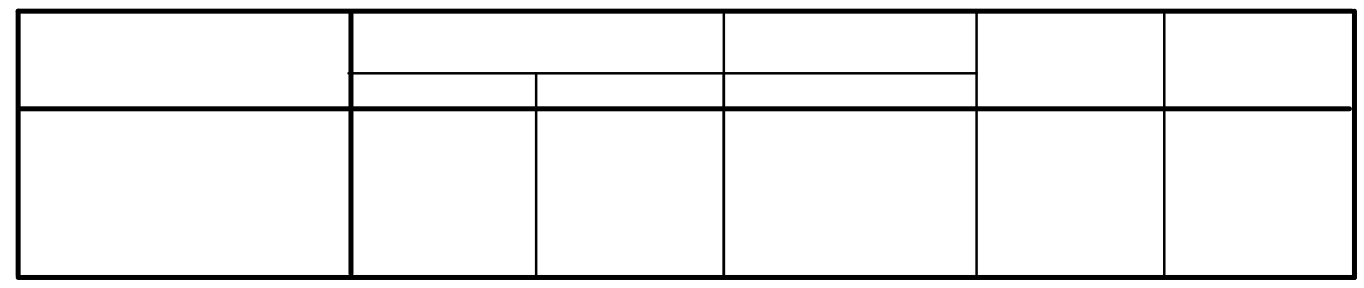

(Sumber : Data Hasil Olahan SPSS)

Berdasarkan tabel 5.5. di ketahui bahwa variabel $\mathrm{X}_{1}(\mathrm{KCA})$ berpengaruh terhadap Pendapatan Sewa Modal hal ini dapat di lihat dari tingkat signifikansi yang lebih kecil dari 0,05 yaitu 0,00 sehingga penelitian ini menerima hipotesis Ha1 yang menyatakan bahwa Kredit Cepat Aman (KCA) berpengaruh terhadap Pendapatan Sewa Modal (PSM).

Dari tabel 5.5. di ketahui bahwa variabel $\mathrm{X}_{2}$ (KREASI) berpengaruh terhadap Pendapatan Sewa Modal hal ini dapat di lihat dari tingkat signifikansi yang lebih kecil dari 0,05 yaitu 0,00 sehingga penelitian ini 
menerima hipotesis Ha2 yang menyatakan bahwa Kredit Angsuran Sistem Fidusia (KREASI) berpengaruh terhadap Pendapatan Sewa Modal (PSM)

Dari tabel 5.5. di ketahui bahwa variabel $\mathrm{X}_{3}$ (KRASIDA) tidak berpengaruh terhadap Pendapatan Sewa Modal hal ini dapat di lihat dari tingkat signifikansi yang lebih besar dari 0,05 yaitu 0,229 sehingga penelitian ini menerima hipotesis $\mathrm{H}_{0} 3$ yang menyatakan bahwa Kredit Angsuran Sistem Fidusia (KRASIDA) tidak berpengaruh terhadap Pendapatan Sewa Modal (PSM).

Dari tabel 5.5. di ketahui bahwa variabel $\mathrm{X}_{4}$ (KRESNA) tidak berpengaruh terhadap Pendapatan Sewa Modal hal ini dapat di lihat dari tingkat signifikansi yang lebih besar dari 0,05 yaitu 0,104 sehingga penelitian ini menerima hipotesis $\mathrm{H}_{0} 4$ yang menyatakan bahwa Kredit Serba Guna (KRESNA) tidak berpengaruh terhadap Pendapatan Sewa Modal (PSM).

\subsection{Pembahasan}

Pengaruh Kredit Cepat Aman (KCA) terhadap Pendapatan Sewa Modal pada PT. Pegadaian (Persero) Kanwil VI Manado dapat dijelaskan sebagai berikut; Pengelolaan Kredit Cepat Aman harus lebih efektif dan efisien agar memberikan nilai tambah bagi perusahaan. Walaupun berdasarkan data yang diperoleh dimana Kredit Cepat Aman (KCA) terus mengalami kenaikan periode tahun 2006 sampai 2011, namun perusahaan tidak hanya diam saja menikmati peningkatan yang ada akan tetapi tetap melakukan perubahan dan inovasi untuk lebih meningkatkan pencapaian.

Perubahan status badan hukum pegadaian dan perubahan pangsa pasar, kondisi perekonomian serta timbulnya peluang bagi kompetitor perlu di tanggapi dan diberi perhatian khusus oleh PT. Pegadaian (Persero). Walaupun kondisi yang menguntungkan bagi perusahaan oleh karena harga emas yang terus mengalami peningkatan, penting bagi perusahaan untuk menampilkan keunggulan kompetitifnya guna mempertahankan pangsa pasar.

Oleh karena Kredit Cepat Aman (KCA) yang merupakan produk utama PT. Pegadaian (Persero) perusahaan harus lebih agresif meningkatkan produk Kedit Cepat Aman (KCA). Dengan peningkatan pemberian produk Kredit Cepat Aman (KCA) kepada nasabah akan meningkatkan pula pendapatan sewa modal perusahaan yang baik untuk pertumbuhan perusahaan. Hal ini sesuai dengan hasil penelitian dimana KCA berpengaruh terhadap PSM, hasil penelitian ini sesuai dengan hasil penelitian dari Sucipto (2006) dengan judul "Analisis faktor-faktor yang mempengaruhi pendapatan sewa modal pada Cabang Perum Pegadaian Kota Surakarta" dimana Kredit Cepat Aman (KCA) mempunyai pengaruh positif dan signifikan terhadap pendapatan sewa modal pada Cabang Perum Pegadaian Kota Surakarta.

Pengaruh Kredit Angsuran Sistem Fidusia (KREASI) terhadap Pendapatan Sewa Modal pada PT. Pegadaian (Persero) Kanwil VI Manado adalah sebagai berikut; Pengelolaan Kredit Angsuran Sistem Fidusia (KREASI) perlu untuk di tingkatkan mengingat semakin banyak kompetitor yang bergerak di bidang industri jasa keuangan yang sama seperti perbankan, finance yang juga semakin agresif memperluas pangsa pasar.

Perlu dilakukan evaluasi terhadap produk yang disalurkan, strategi pemasaran, mempertahankan nasabah yang ada dengan memberikan pelayanan prima yang baik guna meningkatkan penjualan atas produk tersebut. Peningkatan pemberian Kredit Angsuran Sistem Fidusia (KREASI) sangat berpengaruh terhadap Pendapatan Sewa Modal (PSM) dimana jika kredit KREASI mengalami peningkatan maka Pendapatan Sewa Modal akan mengalami peningkatan dan berpengaruh terhadap kelangsungan akan perusahaan. Hal ini sesuai dengan hasil penelitian dimana KREASI berpengaruh terhadap PSM, dan hasil penelitian ini sesuai dengan hasil penelitian Sucipto (2006) dengan judul "Analisis faktor-faktor yang mempengaruhi pendapatan sewa modal pada Cabang Perum Pegadaian Kota Surakarta" dimana Kredit Angsuran sistem Fidusia (KREASI) mempunyai pengaruh positif dan signifikan terhadap pendapatan sewa modal pada Cabang Perum Pegadaian Kota Surakarta.

Pengaruh Kredit Angsuran Sistem Gadai (KRASIDA) terhadap Pendapatan Sewa Modal pada PT. Pegadaian (Persero) Kanwil VI Manado sebagai berikut; Di era sekarang ini kepemilikan atas barang emas mengalami peningkatan, keinginan masyarakat untuk memiliki emas semakin banyak. Kondisi tersebut digunakan PT. Pegadaian (Persero) sebagi sasaran pemberian kredit bagi nasabah yang memiliki barang emas yang banyak lewat produk KRASIDA. Pengelolaan Kredit Angsuran Sistem Gadai (KRASIDA) harus efektif dan efisien agar memberikan nilai tambah bagi organisasi.

Dalam penelitian ini Kredit Angsuran Sistem Gadai tidak berpengaruh terhadap Pendapatan Sewa Modal. Hal tersebut disebabkan oleh penyaluran Kredit Angsuran Sistem Gadai (KRASIDA) sedikit dari tahun ke tahun di bandingkan penyaluran Kredit Cepat Aman dan Kredit Angsuran Sistem Fidusia dapat dilihat pada 
tabel 5.3. Oleh karena itu perlu di lakukan strategi pemasaran yang baik, pelayanan prima kepada nasabah, dan promosi akan meningkatkan pengetahuan masyarakat dan minat mereka atas produk yang diperkenalkan oleh karena kebutuhan hidup yang meningkat karena perubahan ekonomi yang terjadi.

Pengaruh Kredit Serba Guna (KRESNA) terhadap Pendapatan Sewa Modal pada PT. Pegadaian (Persero) Kanwil VI Manado sebagai berikut; Kredit Serba Guna adalah merupakan produk perusahaan yang di peruntukan bagi pegawai. Pengelolaan yang efektif dan efisien akan berpengaruh terhadap pencapaian sasaran. Peningkatan peyaluran Kredit Serba Guna (KRESNA) akan meningkatan Pendapatan Sewa Modal (PSM).

Dalam penelitian ini Kredit Serba Guna tidak berpengaruh terhadap Pendapatan Sewa Modal. Hal tersebut disebabkan oleh penyaluran Kredit Serba Guna (KRESNA) sedikit dari tahun ke tahun di bandingkan penyaluran Kredit Cepat Aman dan Kredit Angsuran Sistem Fidusia.

\section{PENUTUP}

6.1. Simpulan

Dari hasil penelitian dan pembahasan yang dijelaskan sebelumnya maka dapat ditarik kesimpulan sebagai berikut :

3. Kredit Cepat Aman $\left(\mathrm{X}_{1}\right)$ dimana dalam penelitian ini pengukuran variabel adalah jumlah kredit yang disalurkan dari Januari 2006 sampai Desember 2011 berpengaruh terhadap Pendapatan Sewa Modal (Y) dimana dalam penelitian ini pengukuran variabel adalah jumlah pendapatan sewa modal dari Januari 2006 sampai Desember 2011 pada PT. Pegadaian (Persero) Kanwil VI Manado. Dimana dikatakan berpengaruh oleh karena besarnya jumlah kredit yang disalurkan yang terus meningkat dari tahun ke tahun, kenaikan harga emas dari tahun ke tahun, penyebaran outlet-outlet yang mudah di jangkau oleh masyarakat, semakin banyak nasabah yang menggadai. Kenaikan kredit yang disalurkan berpengaruh terhadap pendapatan sewa modal yang terus meningkat seiring kenaikan jumlah kredit yang disalurkan.

4. Kredit Angsuran Sistem Fidusia $\left(\mathrm{X}_{2}\right)$ dimana dalam penelitian ini pengukuran variabel adalah jumlah kredit yang disalurkan dari Januari 2006 sampai Desember 2011 berpengaruh terhadap Pendapatan Sewa Modal (Y) dimana dalam penelitian ini pengukuran variabel adalah jumlah pendapatan sewa modal dari Januari 2006 sampai Desember 2011 pada PT. Pegadaian (Persero) Kanwil VI Manado. Dimana dikatakan berpengaruh oleh karena besarnya jumlah kredit yang disalurkan yang terus meningkat dari tahun ke tahun, kepemilikan kendaraan bermotor oleh masyarakat yang meningkat, penyebaran outlet-outlet yang mudah di jangkau oleh masyarakat, semakin banyak nasabah yang membutuhkan dana untuk menambah modal usaha. Kenaikan kredit yang disalurkan berpengaruh terhadap pendapatan sewa modal yang terus meningkat seiring kenaikan jumlah kredit yang disalurkan.

5. Kredit Angsuran Sistem Gadai $\left(\mathrm{X}_{3}\right)$ dimana dalam penelitian ini pengukuran variabel adalah jumlah kredit yang disalurkan dari Januari 2006 sampai Desember 2011 tidak berpengaruh terhadap Pendapatan Sewa Modal (Y) dimana dalam penelitian ini pengukuran variabel adalah jumlah pendapatan sewa modal dari Januari 2006 sampai Desember 2011 pada PT. Pegadaian (Persero) Kanwil VI Manado. Dimana dikatakan tidak berpengaruh oleh karena besarnya jumlah kredit yang disalurkan sedikit dibandingkan dengan KCA dan KREASI, kepemilikan masyarakat atas emas kebanyakan dalam jumlah sedikit sehingga tidak dapat dijadikan agunan KRASIDA. Jumlah kredit yang disalurkan kecil berpengaruh terhadap pendapatan sewa modal yang kecil dari jumlah pendapatan sewa modal yang diterima perusahaan.

6. Kredit Serba Guna (KRESNA) dimana dalam penelitian ini pengukuran variabel adalah jumlah kredit yang disalurkan dari Januari 2006 sampai Desember 2011 berpengaruh terhadap Pendapatan Sewa Modal (Y) dimana dalam penelitian ini pengukuran variabel adalah jumlah pendapatan sewa modal dari Januari 2006 sampai Desember 2011 pada PT. Pegadaian (Persero) Kanwil VI Manado. Dimana dikatakan tidak berpengaruh oleh karena jumlah kredit yang disalurkan sedikit dan pemberian kredit yang dibatasi. Jumlah kredit yang disalurkan kecil berpengaruh terhadap pendapatan sewa modal yang kecil dari jumlah pendapatan sewa modal yang diterima perusahaan.

7. Secara besama-sama, Kredit Cepat Aman $\left(X_{1}\right)$, Kredit Angsuran Sistem Fidusia $\left(X_{2}\right)$, Kredit Angsuran Sistem Gadai $\left(\mathrm{X}_{3}\right)$, Kredit Serba Guna $\left(\mathrm{X}_{4}\right)$ berpengaruh terhadap Pendapatan Sewa Modal (Y) pada PT. Pegadaian (Persero) Kanwil VI Manado.

6.2. Saran

Dari hasil penelitian dan pembahasan yang dijelaskan sebelumnya maka penulis menyarankan : 
3. Bagi PT. Pegadaian (Persero) Kanwil VI Manado hasil penelitian ini dapat menjadi pertimbangan dalam pengembangan usaha. Untuk Variabel yang diteliti dalam penelitian Kredit Cepat Aman $\left(\mathrm{X}_{1}\right)$ dan Kredit Angsuran Sistem Fidusia $\left(\mathrm{X}_{2}\right)$ penyaluran tetap dipertahankan dan di tingkatkan, peningkatan kualitas pelayanan kepada nasabah, penaksiran barang jaminan yang harus lebih teliti, pemanfaatan kenaikan harga emas dengan optimalisasi uang pinjaman, menghubungi nasabah yang jatuh tempo agar barang tidak di eksekusi lewat pelelangan.

4. Sedangkan untuk variabel Kredit Angsuran Sistem Gadai $\left(\mathrm{X}_{3}\right)$ dan Kredit Serba Guna $\left(\mathrm{X}_{4}\right)$ ini perlu diperluas sesuai dengan kebutuhan pasar dengan melakukan promosi dan strategi pemasaran yang baik. Mengkaji kembali sistem dan prosedur pemberian kredit.

\section{DAFTAR PUSTAKA}

Abdula, Th., dan F. Tantri, 2002. Bank dan Lembaga Keuangan. Jakarta : PT. RajaGravindo Persada.

Divisi Litbang. 2009. Pemasaran Kantor Pusat Perum Pegadaian.

Divisi Usaha Syariah. 2005. Perum Pegadaian.

Ikatan Akuntan Indonesia, 2009. Pernyataan Standar Akuntansi Keuangan No. 23 (revisi 2009). Jakarta Dewan Standar Akuntansi Keuangan.

Ghozali, Imam, 2005. Aplikasi Analisis Multivariate dengan Program SPSS, Edisi Ketiga, Semarang: Badan Penerbit Universitas Diponegoro.

Kuncoro, Mudrajad. 2009. Metode Riset untuk Ekonomi dan Bisnis. Jakarta: Erlangga.

Melayu Hasibuan, 2009. Dasar-Dasar Perbankan. Jakarta: Gramedia

Pedoman Operasional Kredit KRASIDA. 2004.

Priyatno, Duwi, 2012. Belajar Cepat olah Data Statistik dengan SPSS. Yogyakarta: Andi offset.

Republik, Indonesia, 1998. Undang-Undang No 10 Tahun 1998 tentang Perubahan atas Undang-undang No

7 Tahun 1992. Lembaga Negara RI Tahun 1998. Kementerian Keuangan Jakarta.

Sinungan, Muchdarsyah. 2002. Dasar-dasar dan Teknik manajemen Kredit. Jakarta:PT. BinaAksara.

Suci, Dwikania S, 2011, Pengaruh Pemberian Kredit Gadai KCA terhadap Pendapatan Sewa Modal Pada Pegadaian Cabang Pungkur Bandung, Fakultas Ekonomi Komputer Indonesia,Penelitian Komputer Indonesia, Bandung.

Sucipto, 2006, Analisis Faktor-Faktor Yang Mempengaruhi Pendapatan Sewa Modal Pada Cabang Perum Pegadaian Kota Surakarta, Fakultas Ekonomi Universitas Muhammadiyah,Penelitian Muhammadiyah, Surakarta.

Triandaru, S., dan T. Budisantoso, 2006. Dasar-dasar dan Teknik manajemen Kredit. Jakarta:PT. BinaAksara. Tim OPP Kanwil Malang. 2006. 